\title{
Franjo Kogoj's Role in the Yugoslav Academy of Sciences and Arts 1947-1972
}

\author{
Stella Fatović-Ferenčić (D) ${ }^{1,2}$, Martin Kuhar ${ }^{1}$, Silvija Brkić Midžić2 , Marko Pećina ${ }^{2,3}$ \\ ${ }^{1}$ The Division for the History of Medical Sciences, Croatian Academy of Sciences and Arts, Zagreb, Croatia \\ ${ }^{2}$ Croatian Museum of Medicine and Pharmacy, Croatian Academy of Sciences and Arts, Zagreb, Croatia \\ ${ }^{3}$ School of Medicine, University of Zagreb, Zagreb, Croatia
}

OPEN ACCESS

Correspondence:

Prof. Stella Fatović-Ferenčić stella@hazu.hr orcid.orcid.org/0000-0001-9637-4792

This article was submitted to RAD CASA Medical Sciences as the essay

Conflict of Interest Statement: The authors declare that the research was conducted in the absence of any commercial or financial relationships that could be construed as a potential conflict of interest.

Received: 12 April 2020 Accepted: 24 June 2020 Published: 22 July 2020

Citation

Fatović-Ferenčić S, Kuhar M, Brkić Midžić $S$ and Pećina M. Franjo Kogoj's

Role in the Yugoslav Academy of

Sciences and Arts 1947-1972

RAD CASA - Medical Sciences.

$543=50-51(2020): 79-88$ DOI: https://dx.doi.org/10.21857/

yrvgqterd9

Copyright (C) 2020 Fatović-Ferenčić S, Kuhar M, Brkić Midžić S and Pećina M. This is an open-access andiclecina $M$. This is an open-access article distribcommons Atribution ticense (CC BY).

Thmons Attribution License (CC BY).

The use, distribution or reproduction

other forums is permitted, provided the original author(s) and the copyright owners(s) are credited and that the original publication in this journal is cited, in accordance whit accepted adacemic practice. No use, distribution or reproduction is permitted which does not comply with these terms.

\section{ABSTRACT:}

Up until now, extensive research has been conducted on the life and legacy of Franjo Kogoj (18941983) who was a prominent Croatian dermatovenereologist, full-time professor and Dean of the Zagreb School of Medicine, long-standing head of the University Department of Dermatology and Venereology, Zagreb University Hospital Centre, head of the Department of Dermatovenereology, Zagreb University School of Medicine, as well as a full member of the Yugoslav Academy of Sciences and Arts (YASA). In this paper, we shall present Kogoj's role in YASA after he was elected its full member in 1947, especially during his mandates as the first Secretary of the Department of Medical Sciences (1950-1958) and as Vice-President of the Academy (1958-1972). We shall follow his various publishing activities, international networking, as well as his role in the establishment of important medical institutions. The paper is based on Kogoj's articles published in Academy's periodicals, the documentation kept at the Academy's Division for the History of Medical Sciences and fragments of his material heritage preserved in the Croatian Museum of Medicine and Pharmacy of the Croatian Academy of Sciences and Arts.

KEYWORDS: Franjo Kogoj, Yugoslav Academy of Sciences and Arts, Department of Medical Sciences YASA, dermatovenereology, Croatia, 20th century

\section{SAŽETAK:}

Uloga Franje Kogoja u JugoslavensKoj aKademiji ZnANosti I UMJETnOSTI I947-I 972 O Franji Kogoju (1894. - 1983.), dermatovenerologu, redovitom profesoru Medicinskog fakulteta Sveučilišta u Zagrebu, dekanu i prodekanu u nekoliko mandata, šefu dermatovenerološke klinike tijekom četrdeset godina, redovitom članu Jugoslavenske akademije znanosti i umjetnosti, do sada je objavljen niz članaka. U ovom radu prezentirat ćemo njegovu ulogu u tadašnjoj JAZU nakon izbora za redovitog člana (1947.), kao prvog tajnika Odjela za medicinske nauke (1950 - 1958.) te kao potpredsjednika Akademije (1958. - 1972.), prateći njegove aktivnosti u realizaciji izdavačkih projekta, međunarodne razmjene, osnutka medicinskih ustanova i organizaciji kongresa. Pritom ćemo se većim dijelom koristiti Akademijinim publikacijama, dokumentacijom pohranjenom u Odsjeku za povijest medicinskih znanosti HAZU te dijelovima Kogojeve materijalne ostavštine, pohranjene u Hrvatskome muzeju medicine i farmacije HAZU.

KLJUČNE RIJEČI: Franjo Kogoj, Jugoslavenska akademija znanosti i umjetnosti, Odjel za medicinske nauke JAZU, dermatovenerologija, Hrvatska, 20. stoljeće 
Figure 1. Franjo Kogoj, author Vanja Radaus, Gliptotheque CASA

Franjo Kogoj's (1894-1983) role and contributions to the development of Croatian dermatovenereology have been examined in a series of articles ${ }^{1-20}$, some of which were published by the Academy publications ${ }^{21-25}$ (Figure 1). Unlike his printed works, Kogoj's material heritage has not yet been a subject of scientific analysis. For a number of years it has been stored in the Division for the History of Medical Sciences of the Croatian Academy of Sciences and Arts, later reassigned to the Croatian Museum of Medicine and Pharmacy of the Croatian Academy of Sciences and Arts (CASA) upon its foundation in 2014. The Kogoj Collection consists of framed photo portraits of 55 prominent dermatologists from all over the world, as well as 48 charters related to Kogoj's achievements and memberships in various professional societies, many of them international. Honorary diplomas, charters and acknowledgments have been awarded to Kogoj throughout his career for his distinguished role in the development of dermatovenereology, medicine and Croatian society in general. The greatest number of charters are related to Kogoj's honorary and other memberships in professional societies (in Europe and overseas) awarded to him in the period between 1930 and 1976, to memberships in other domestic and international medical societies (Croatian Medical Association, Slovene Medical Society, Yugoslav Medical Societies' Union) for the period between 1961 and 1977, and honorary plaques and acknowledgements (from schools of medicine in Zagreb, Sarajevo, Bratislava, Ljubljana and Rijeka) in the period from 1961 to 1975. The collection also includes diplomas and charters related to his membership in various academies that he received in the period from 1947 to 1975 . This rich material forms the basis of an exhibition dedicated to Kogoj which will be opened in spring 2021 , celebrating $100^{\text {th }}$ anniversary of the Department of Dermatovenerology in Zagreb (established in 1921). This material is also a solid comparative foundation for revising the existing knowledge related to Kogoj's honorary and other memberships in various associations, as well as the reconstruction of his international networking.

Despite the fact that Kogoj became a full member of the Yugoslav Academy of Sciences and Arts (YASA) already in 1947, and that he was the secretary of the Department of Medical Sciences (1950-1958) and the Vice-President of the Academy (1958-1972), a detailed overview of his role in the Academy has not yet been published. In this article, we will present some of Kogoj's most important activities in the Academy, such as the establishment of medical institutions, international scientific exchanges, organization of symposia and lectures, as well as numerous publishing projects. To that end, we will use the data published in the Academy's bulletins (Ljetopis and Rad), the documentation kept at the Division for the History of Medical Sciences, as well as the segments of the material heritage stored in the Croatian Museum of Medicine and Pharmacy.

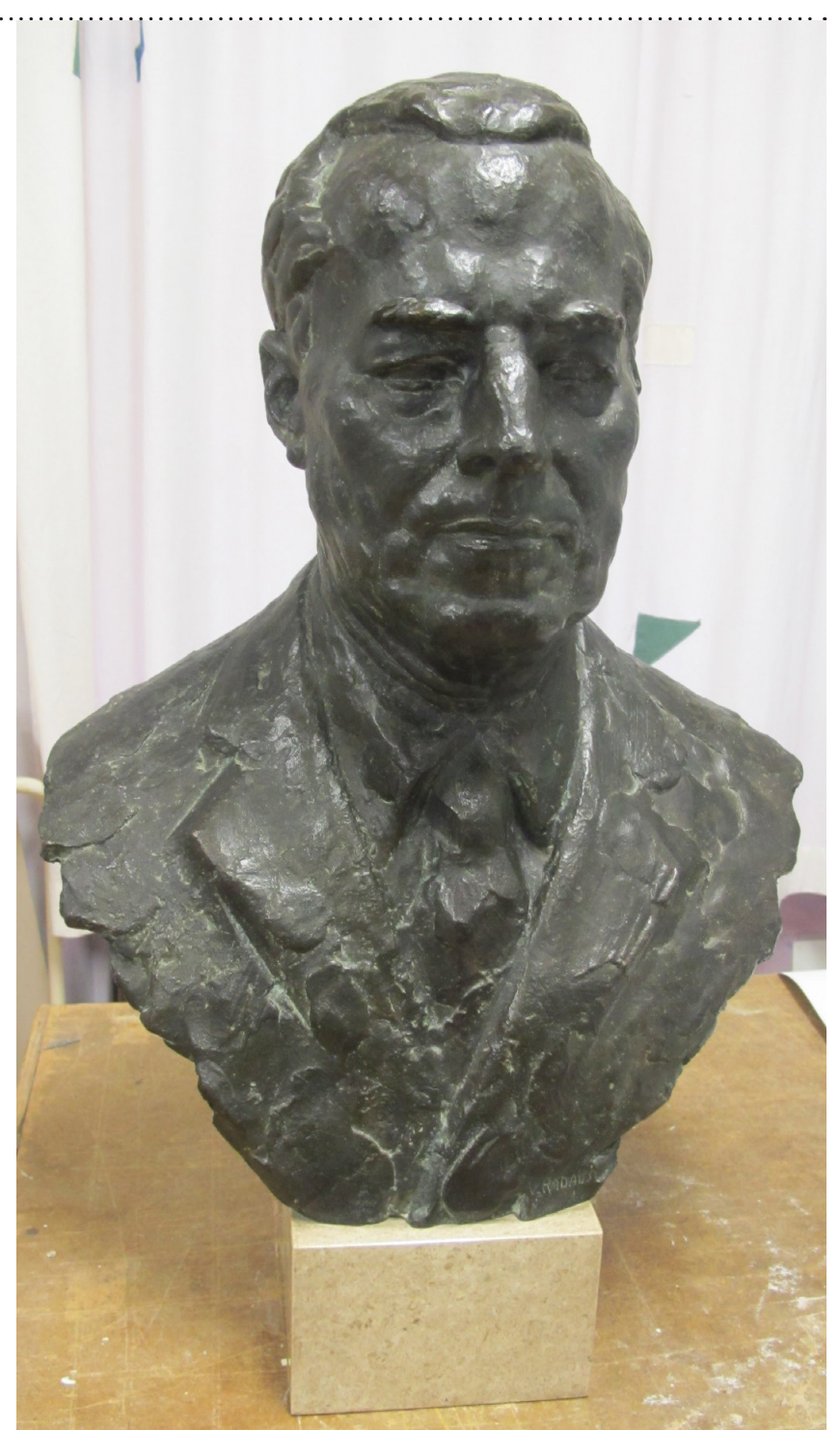

Full MEMBER OF THE ACAdemy IN 1947

Yugoslav Academy of Sciences and Arts was founded in Zagreb on April 29, 1861 by the Croatian parliament. After confirming its statute on March 4, 1866, the parliament elected the first 16 members of the Academy. Bishop Josip Juraj Strossmayer was named its patron, while the eminent Croatian historian Franjo Rački was elected President of the Academy. From 1941 to 1945 , the Academy functioned under a new name - the Croatian Academy of Sciences and Arts - and again under its old name YASA after the Second World War. After the establishment of the democratic Republic of Croatia, the Croatian parliament on June 26, 1991 passed a new law on the Croatian Academy of Sciences and Arts. The Parliament named it the highest scientific and art institution in Croatia, while acknowledging its overall influence and historical role.

The Natural and Medical Sciences Department of the former Yugoslav Academy was founded in 1947. In that same year eminent representatives of various medical specialties and professors from the School of Medicine in Zagreb were elected as members: Branimir Gušić, professor of otorhinolaryngology; 


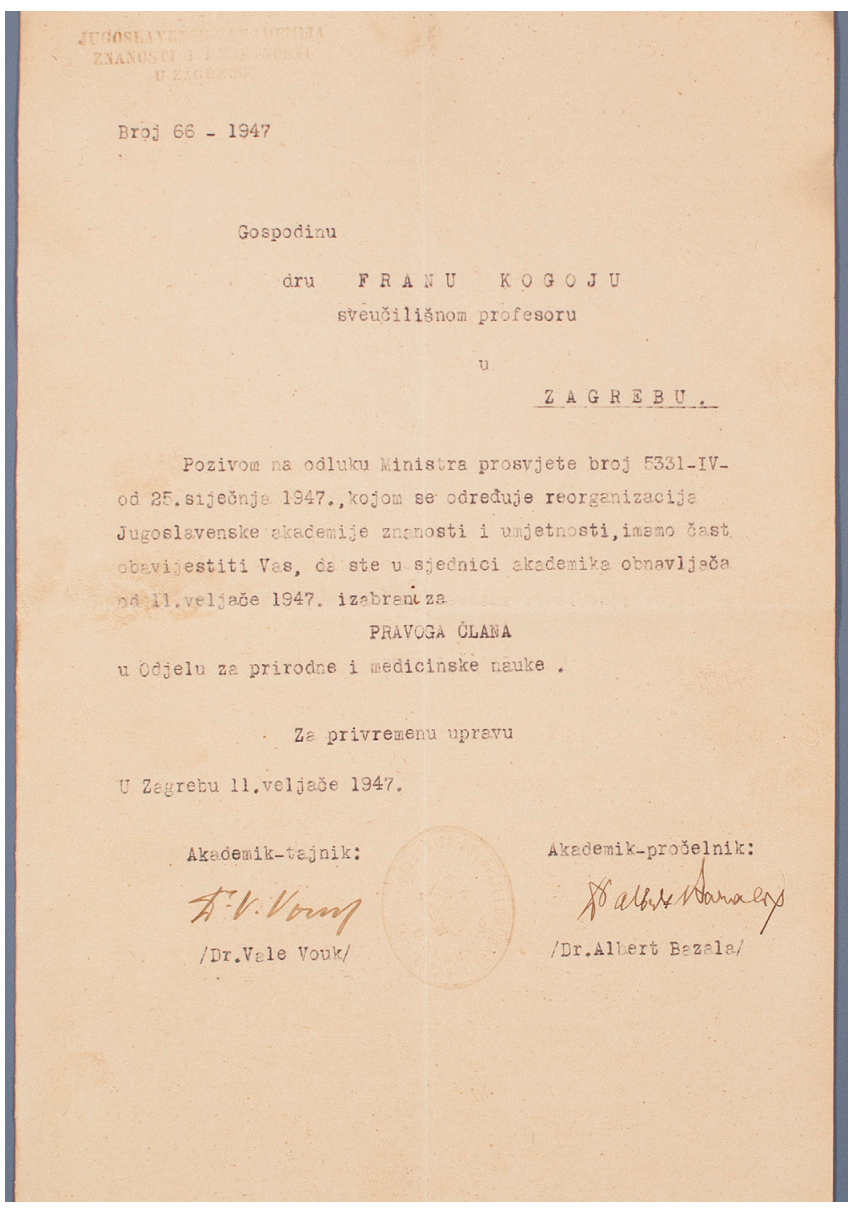

Figure 2. Certificate of Franjo Kogoj's full membership in YASA, 1947, HMMF4486

Franjo Kogoj, professor of dermatovenereology and head of the Department of Dermatovenereology in Zagreb; and Andrija Štampar, professor of social medicine, who was elected as member of the Philosophy and Social Sciences Section ${ }^{26}$ (Figure 2). Kogoj's biography, published in journal Ljetopis on the occasion of his membership in the Academy, states that he had previously published several monographs $s^{27-30}$ and 87 scientific articles. At the age of 53 , he was a corresponding and/or honorary member of several dermatovenereological societies, a member of several dermatovenereology journals' editorial boards, president of the Section for Dermatovenereology of the Croatian Medical Association and a participant in a number of Croatian and international conferences ${ }^{31}$. One year after his election to membership in the Academy, Kogoj published a paper on the complex topic of eczema and various theoretical models explaining its etiology, which was published in the Academy's Rad ${ }^{32}$ (Figure 3). This comprehensive article reveals the breadth of Kogoj's erudition, as well as his capacity to observe and differentiate between various dermatological phenomena occurring in children and adults. Two years after being elected full member of the Academy, Kogoj gave a lecture On Allergy $y^{33}$, a subject that continued to preoccupy him throughout his working life. In the same year, the Academy published Kogoj's second edition of the book Terapija sifilisa [The Treatment of Syphilis] ${ }^{34}$, in which he presented an original method of treating syphilis, which involved two crucial factors: critical moment and liqour quinquenio. He returned to this topic repeatedly as a lecturer and as an author. ${ }^{35}$

At the time when Kogoj was elected full member, the Academy consisted of the Department of Philosophy and Social Sciences,

\section{JUGOSLAVENSKA AKADEMIJA ZNANOSTI I UMJETNOSTI}

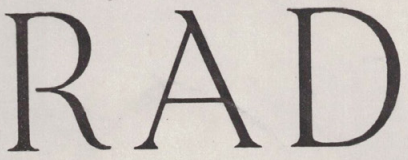

KNJIGA

273

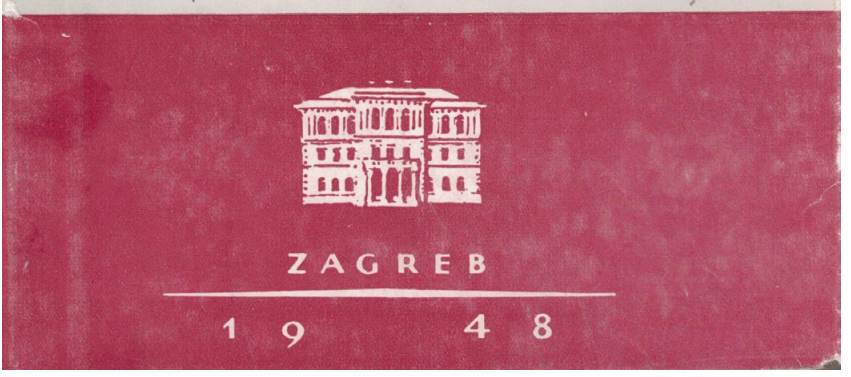

Figure 3. Kogoj's first article published in the Academy's journal "Rad", vol. 273, 1948

Department of Mathematical, Physical and Technical Sciences, Department of Natural and Medical Sciences, Department of Language and Literature and Department of Art and Music. The law on Yugoslav Academy from 1947 planned for the establishment of new scientific and art institutions. At the same time, natural and medical sciences were developing more rapidly, so the number of members from these fields grew. This eventually led to the splitting of the Department of Natural and Medical Sciences into the Department of Natural Sciences and the Department of Medical Sciences.

\section{The Secretary of the Department of Medical SCIENCES, 1950-1958}

After the Department of Medical Sciences was formed in 1950, Franjo Kogoj was named its first Secretary. He performed this duty in two mandates until the end of 1958. It was a very intensive period for the Academy, marked with growth and development of museums and scienfitic departments. Multiple institutes and museums were being integrated into the Academy. At that time, the Academy had its publishing department with a printing office, as well as a scientific library. The President of the Academy was Andrija Štampar (1888-1958), who had substantial international experience, including the crucial role in the establishment of the World Health Organization ${ }^{36}$. His qualifications proved to be more than beneficial to the Academy as well. Kogoj was also internationally renowned and, although a clinician, partial to viewing skin and venereal diseases through their interaction with ecology, geography and society in general. He dedicated a part of his investigations to professional dermatoses of factory workers ${ }^{37}$. Both Štampar and Kogoj 


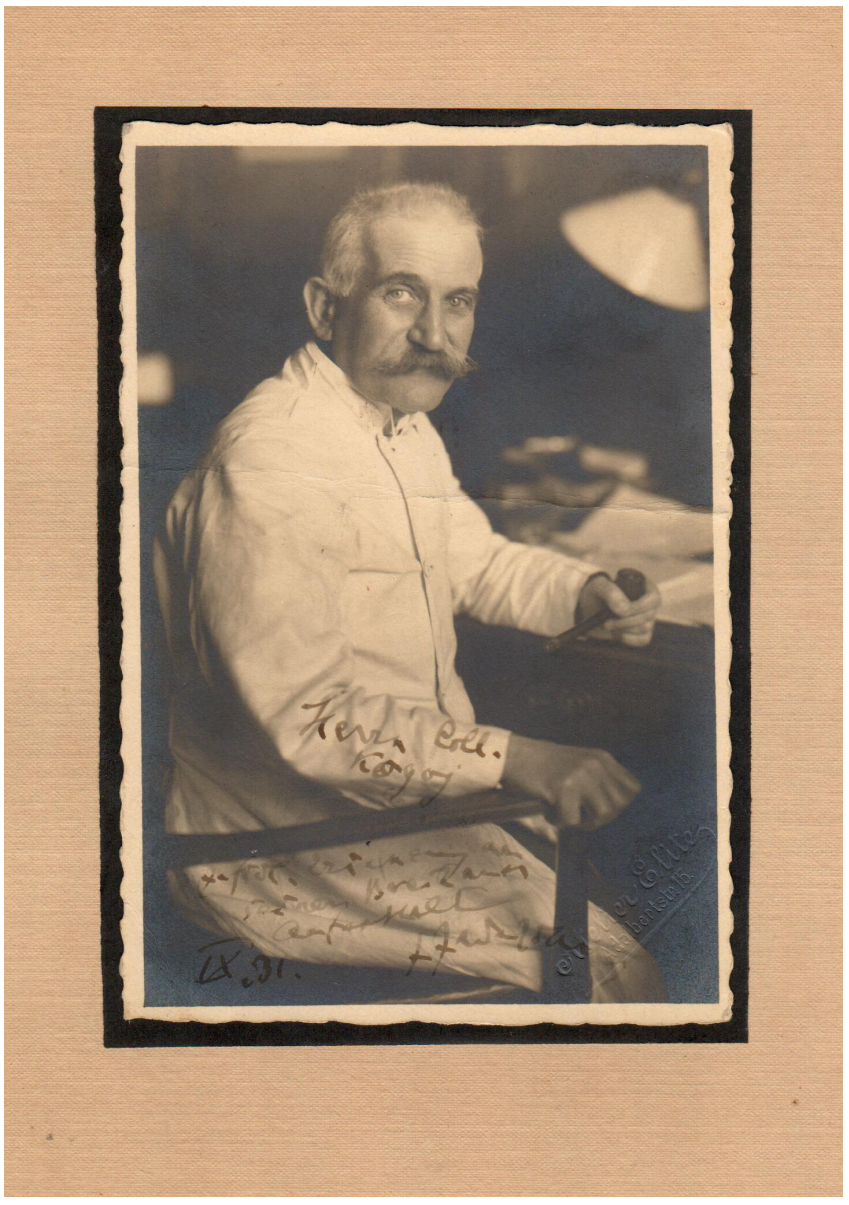

Figure 4. Josef Jadassohn (1863-1936), Wroclaw, 1931, HMMF-4549

advocated the globalization of medicine through their activities in the Academy. Prominent scientist were being invited to give lectures, while scientific journals and other publications were being exchanged and international and inter-academic connections were being developed. Academy also financially supported the participation of its members at international symposia. For example, in 1950 Kogoj received financial support to participate at the German Congress of Dermatologists in Heidelberg, at which he lectured about penicillin as an antisyphilitic drug. Kogoj returned to this topic repeatedly, especially during his field research of endemic syphilis in Bosnia ${ }^{38}$.

During Kogoj's mandate, the Department of Medical Sciences worked diligently on the establishment of new scientific research centers. As the President of the Academy, but also as a member of the Department of Medical Sciences, Štampar initiated the establishment of the Institute for Workplace Hygiene in 1947, while Kogoj advocated for the establishment of an allergology institute ${ }^{39}$. Incorporating the ideology of the then popular social medicine, priorities were being set taking into consideration the interests of the working class and socially endangered population. Thus, the biggest support was given to those institutions that would identify and explore various factors compromising the health and well-being of the wider population. This aspect was reflected within the Department of Medical Sciences, which coordinated the Section for Medical Sciences and the Section for Veterinary Sciences, the Center for Leptospirosis, as well as the Biochemical Laboratory of the Institute for Workplace Hygiene. During 1952, the Academy merged all medical institutes and laboratories and established the Institute for Medical Re-

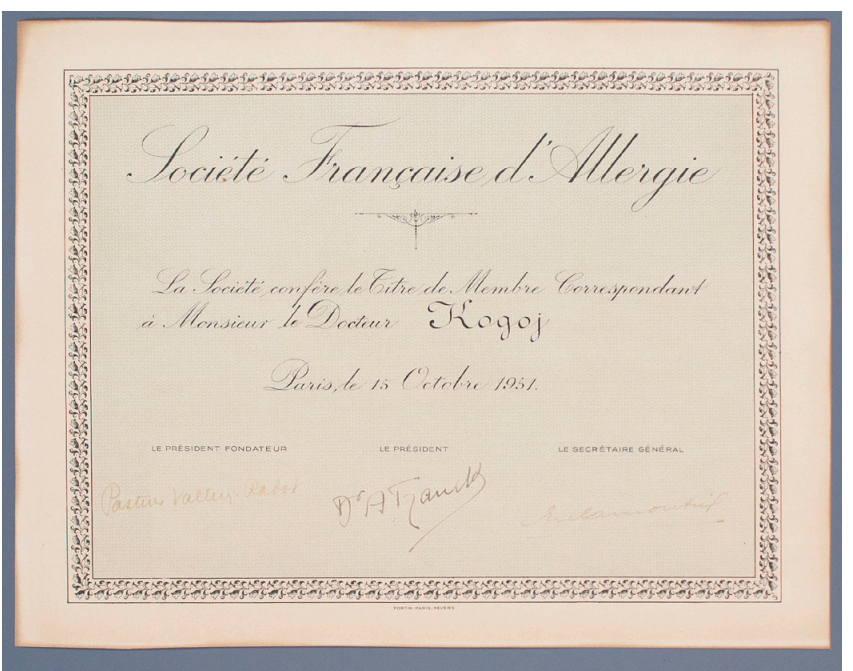

Figure 5 Charter of Franjo Kogoj as a corresponding member of the French Society of Allergology, Paris, 1951, HMMF-4476

search and Workplace Hygiene, which developed at an impressive pace. Its head was Branko Kesić, who also edited the journal Arhiv za higijenu rada [Archive for the Workplace Hygiene] established in 1950. Members of the Department of Medical Sciences at the time were: as full members Ivo Babić, Ivo Čupar, Branimir Gušić, Franjo Kogoj, Božidar Oklješa, Drago Perović, Andrija Štampar and Franjo Durst; and as corresponding members Branko Kesić, Ivo Tomašec and Otmar Trausmiller. The professor of anatomy at the School of Medicine in Zagreb Drago Perović regularly reported about the activities of the Section for Medical Sciences, while the veterinarian Božidar Oklješa referred about the activities of the Section for Veterinary Sciences. Meetings of the Section for Medical Sciences were not only dedicated to technical questions, but also incorporated lectures and discussions on various topics, especially those that were being prepared for publishing ${ }^{40}$.

In the 1950s, the interest for allergy permeated various medical specialties. Kogoj's interest toward allergology had its roots in the time of his specialization, when he was impressed with experimental work and immunological research conducted in Josef Jadassohn's laboratories in Breslau (now Wroclaw in Poland). Thus, several photo portraits of dermatologists from Breslau form part of the Kogoj Collection, such as the photo portrait of Josef Jadassohn (1863-1936), the pioneer in allergology and the inventor of the patch test for contact dermatitis (Figure 4), and Hans Biberstein (1889-1965), who worked in Jadassohn's clinic and explored immunology and allergology. Kogoj's first papers on allergy were published in the late 1920s, and he continued to explore this topic throughout his career. Unsurprisingly, Kogoj gave an incentive in 1951 to organize a congress on allergy at the Academy, and the lectures given at the congress were published in Rad already in the following year ${ }^{41}$. His activities were also recognized internationally, so in 1952 he received the charter of the French Society of Allergology signed by its president Arnauldt Tzanck (Figure 5). Together with Albin Brnobić, in 1952 Kogoj founded the Allergology Section of the Croatian Medical Association, and was elected its first president ${ }^{42}$. In 


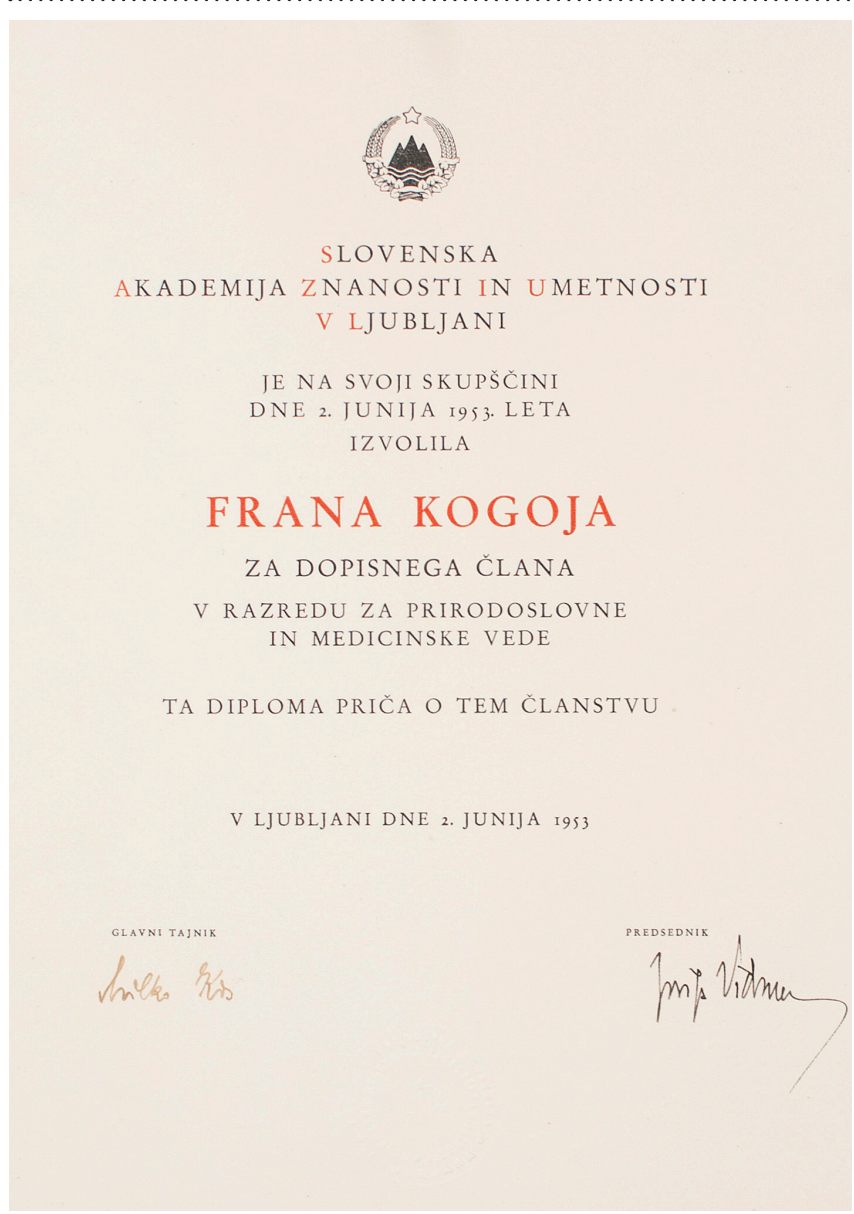

Figure 6. Charter of Franjo Kogoj as a corresponding member of the Slovene Academy of Sciences and Arts, Ljubljana, 1953, HMMF-4487

1953, he became a corresponding member of the Slovene Academy of Sciences and Arts (Figure 6).

Kogoj was undoubtedly responsible for inviting prominent dermatologists to the Academy as guest speakers. One of them was Alfred Marchionini (1899-1965), the German dermatologist famous for the 1950 establishment of the influential journal Der Hautarzt, which he edited for a number of years. From the same year there is also Kogoj's charter of his honorary membership at the Hamburg Dermatological Society, signed by Marchionini, as well as Marchionini's photo portrait with a dedication to Kogoj. Upon Kogoj's invitation, Marchionini gave a lecture at the Academy on April 22, 1952. Kogoj translated the abstract of the lecture, which was published in Ljetopis ${ }^{43}$. Under Kogoj's editorship, the Academy also published Izvješća dermatovenereološke klinike u Zagrebu [The Reports of the Department of Dermatovenereology in Zagreb], which addressed topics such as micoses, burns, syphilis and other conditions ${ }^{44}$ (Figure 7). In his chapter in the Reports, Kogoj presented his idea of the antisyphilitic therapy, emphasizing that it was "being built on foundations that derive from the biology of white treponeme and from the biology of the diseased organism" ${ }^{45}$.

In 1954, the Department of Medical Sciences published another issue of Rad (book 299), while Kogoj with his associates authored the four hundred-page book Spolne bolesti [Venereal Diseases] published by the Academy. The Department of Medical Sciences also started preparing a new publication on geriatrics, and several lectures were being given on this subject during the Department's regular meetings. The work on collecting medical

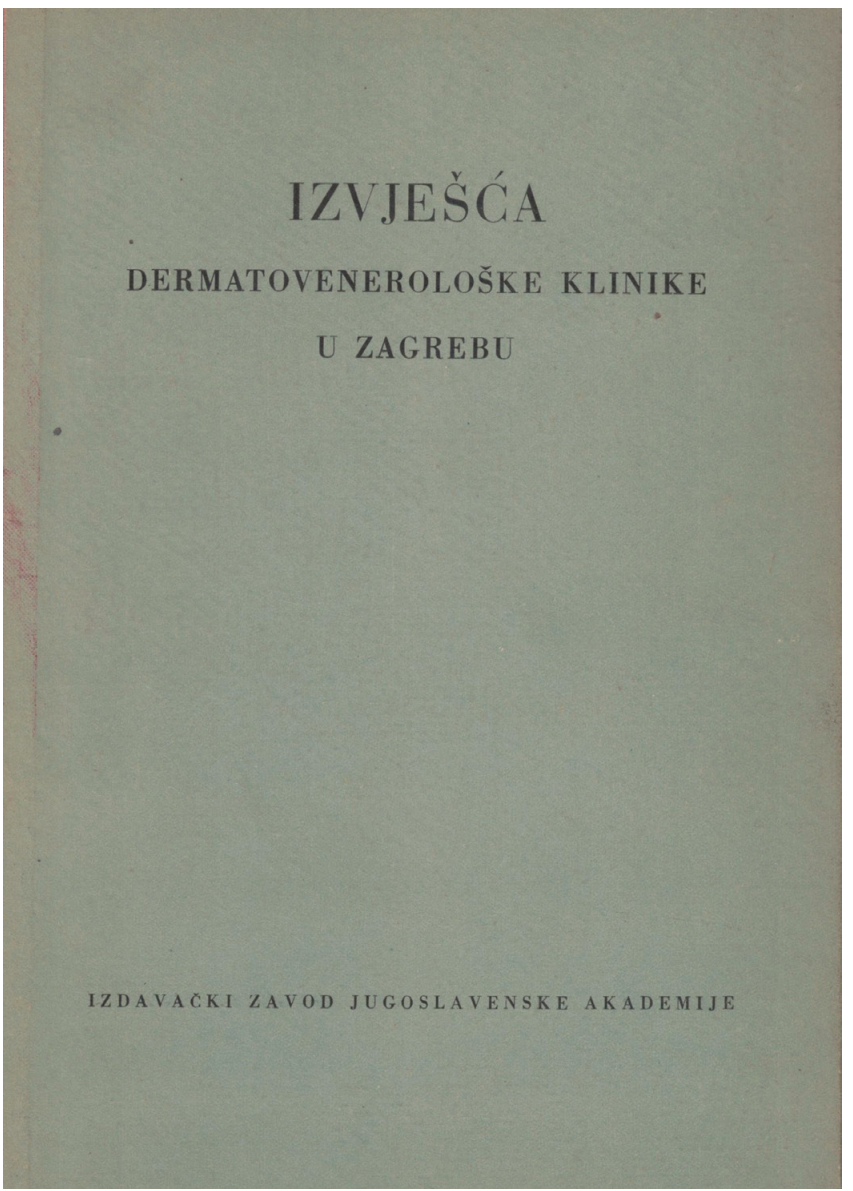

Figure 7 Report of the Department of Dermatovenereology, ed. Franjo Kogoj, YASA, Zagreb, 1952

and veterinarian terminology was also taking place. Given his important role in helping young scientists, Kogoj was assigned by the Academy's Council to participate at the CIOMS (Conseil des organisations internationales des sciences medicales) meeting in London in October $1954^{46}$.

In 1955, Kogoj published a paper O generaliziranoj kandidijazi [On Generalized Candidiasis] in the Academy's journal Rad ${ }^{47}$. In the same year, he gave a lecture $O$ postanku nekih bolesti [On the Genesis of Certain Diseases] at the Academy. The Academy granted him financial support to participate at the international congress in Lille, where he gave a lecture on professional dermatoses, as well as his trip to Munich, where he gave a keynote at the meeting of the Society of Dermatologists. At the time, the grants were being given only to the candidates that applied for active participation in the international congresses, while the candidate did not necessarily need to be Academy's employee or its member. In his reports of the annual meetings by the Academy's Assembly, Štampar emphasized this openness of the Academy "towards all who wish to advance science and art and its dedication to provide financial support" ${ }^{48}$. During 1955, the German dermatology journal Der Hautartzt published a paper by Alfred Marchionini dedicated to Kogoj on the occasion of his $60^{\text {th }}$ birthday ${ }^{49}$.

Among the many activities coordinated by the Department of Medical Sciences, one of the most progressive occurred within the Division for the History of Medicine of the Institute for Medical Research, led by the historian of medicine Mirko Dražen Grmek (1924-2000). In 1955, the Academy published 


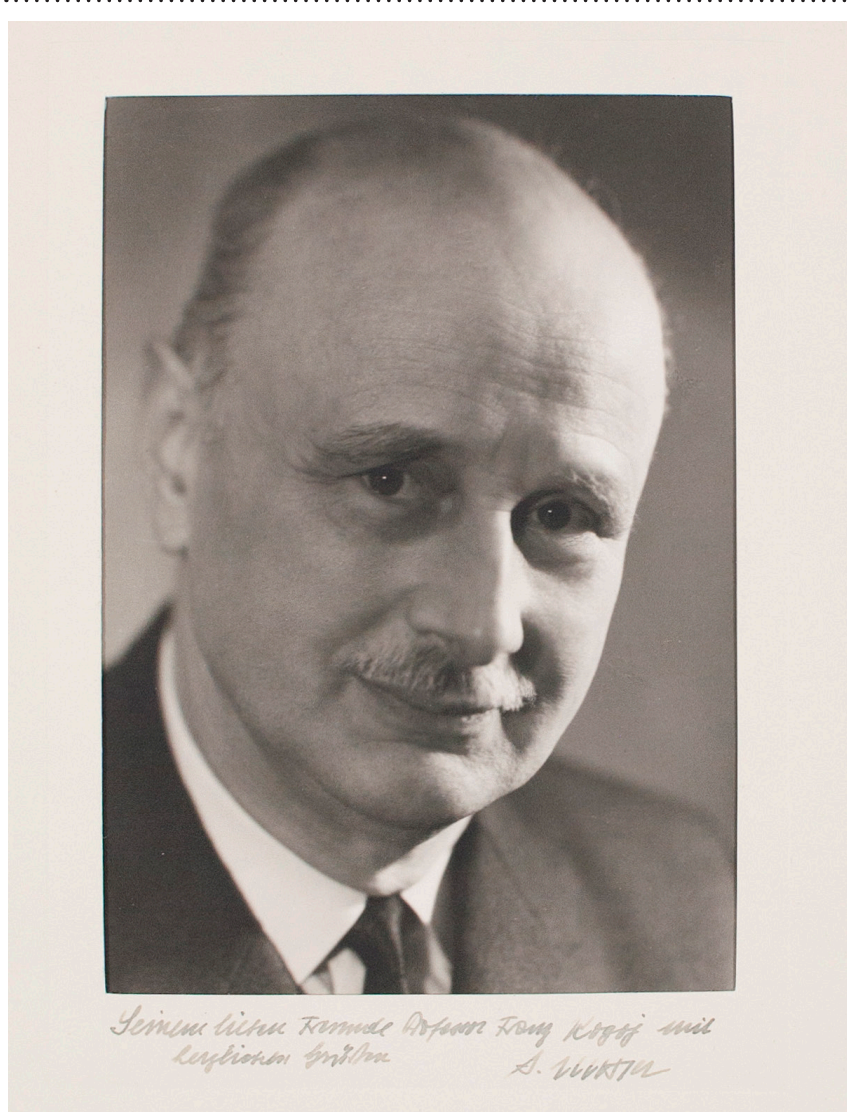

Figure 8. Anton Musger (1898-1983), corresponding member of YASA, Graz, circa 1960, $H M M F-4562$

Grmek's work Hrvatska medicinska bibliografija [Croatian Medical Bibliography ${ }^{50}$, while the members of the Department reviewed papers submitted by other historians of medicine. The Department sent Grmek on a study leave in Padua and Venice for two weeks, after which a lengthy report of the visit was published in Ljetopis $^{51}$. At that time, the Department reflected the care which was being put into the development of the Croatian medical terminology. In 1955, Drago Perović reported that the project of cataloging the terminology had already commenced, and during one of the Department's regular meetings, he suggested the first one thousand terms, while also stimulating the discussion about the Croatian terms for tonsils ${ }^{52}$.

Inter-academy contacts were established between related Academy departments of the former state. For example, together with Otmar Trausmiller, Kogoj participated as the Department representative at the meeting of medical departments of the Three Academies and the Science Society of Bosnia and Herzegovina held in Ljubljana on February 27, $1957^{53}$. In the same year, Kogoj participated at the international congress in Stockholm and entered the selection for the Preparatory Committee of the Twelve for the next dermatology congress, which was to be held in Washington in $1962^{54}$.

Publishing business in the Academy developed according to its financial constraints. For instance, up until 1958 the Academy published fifty books annually, while in 1958 that number was almost halved at only twenty-six books due to a significantly smaller budget. In 1958 the number of employees also dwindled, since the Balneo-climatological Division, as well as the Division for Immunochemistry of the Institute for Medical Research were merged with the School of Medicine in Zagreb ${ }^{55}$. During 1958, Simpozion o gerontologiji [Symposium on Geron-

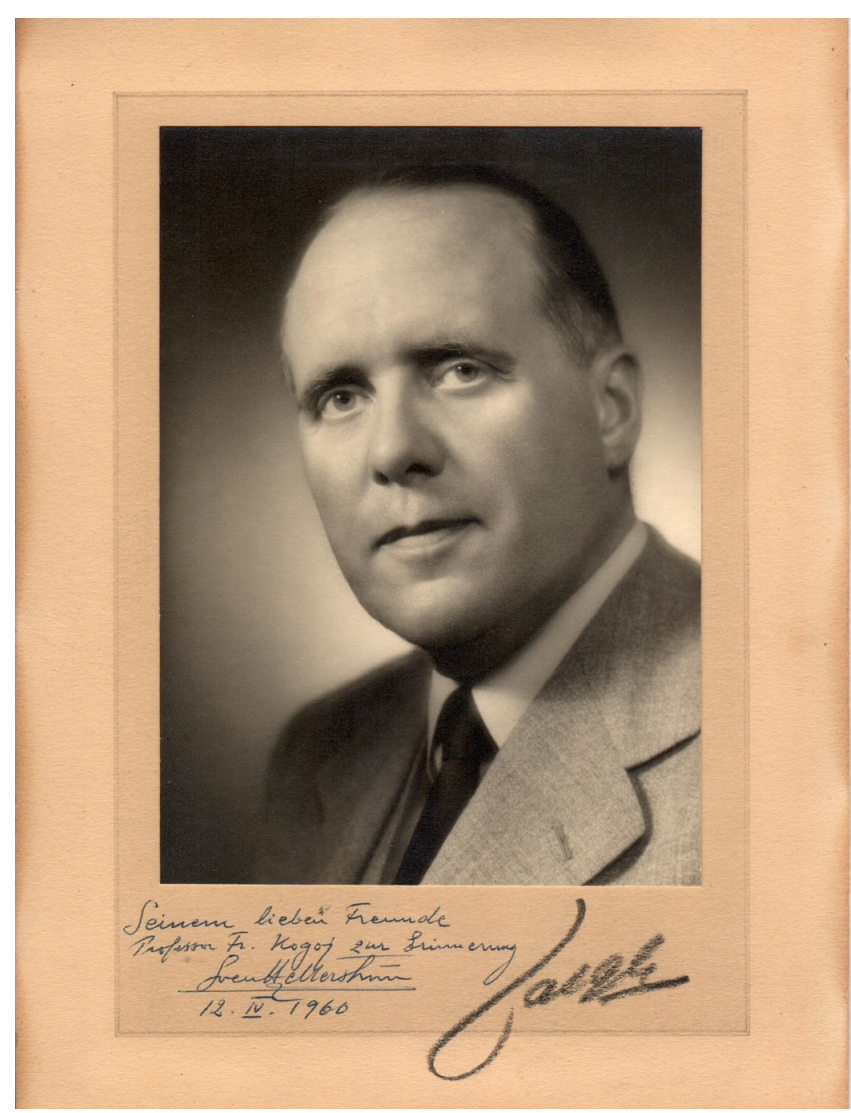

Figure 9 Sven Hellerström (1901-1977), Stockholm, 1960, HMMF-4546

tology] was published and the activities related to the study of social pathology in the near future were agreed. Further on Rad number 316 was published and activities related to the research of medical terminology were continued, while those related to the veterinary terminology were temporarily suspended. Financial grants for congresses continued to be given to active participants, among others to Kogoj, who traveled to Krakow for the meeting of the Polish Dermatovenereological Society, where he was awarded a charter for honorary membership. Kogoj also received the financial grant for the Third International Congress on Allergy in Paris.

\section{Vice-President of the Academy (1958-1972)}

In January 1959, Fellow of the Academy Ivo Čupar replaced Kogoj as the Secretary of the Department of Medical Sciences. Kogoj was elected Vice-President of YASA on November 23, 1958, a position he held until March 15, 1972. As Vice-President and member of the Academy's Presidency, Kogoj was involved in the ongoing administrative work, especially the fostering of inter-academic and international cooperation. The Kogoj Collection enables the reconstruction of the networking behind some of the keynote lectures given by prominent international researchers in the Academy. Undoubtedly, the person behind Musger's (1952) and Marchionini's (1954) lectures was Kogoj, who maintained close contacts with both of them. Austrian dermatologist Anton Musger (1898-1983) was famous in our academic community for his initiative to hold interclinical colloquia between Graz and Zagreb, at which he also gave lectures. As an ex-rector of the University of Graz, Musger was present at the ceremonial meeting of the Teacher's Council of the School of Medicine in Zagreb held on December 20, 1967, when Kogoj was awarded a charter documenting his honorary membership at the School ${ }^{56}$. Musger also held a keynote lecture 


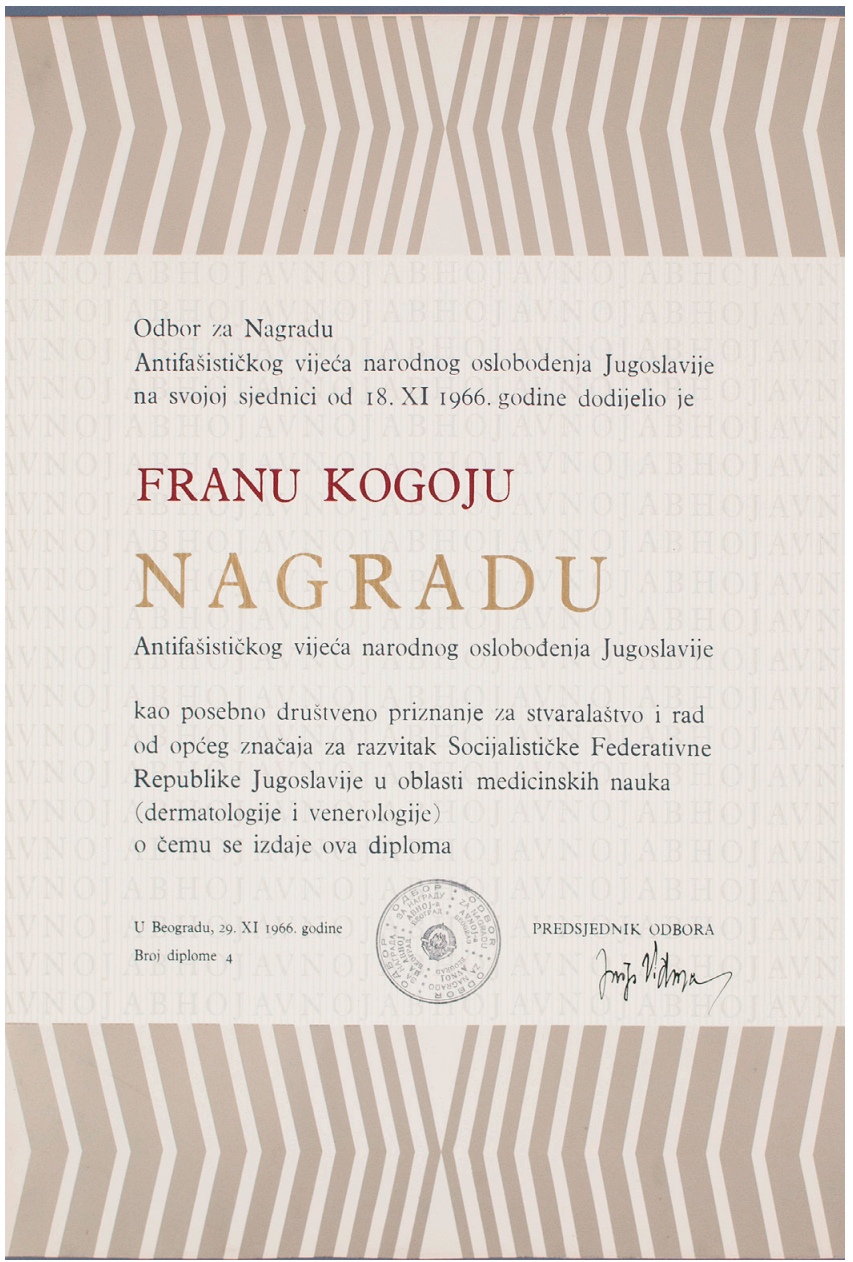

Noviji podaci o kožnoj retikulozi [New Data on Reticulosis of the Skin] in 1954, and on June 20, 1969 he was elected corresponding member of YASA57 (Figure 8).

A notice about the lecture held by the renowned Swedish dermatologist Sven Hellerström (1901-1977), responsible for his description of Lyme borreliosis, was published on the pages of Ljetopis $^{58}$. It was accompanied with information regarding Kogoj's participation at the Congress of Dermatovenereologists in Stockholm in 1957, presided by Sven Hellerström, and included the portrait with Hellerström's dedication to Kogoj from 1960 (Figure 9). It is without a doubt that Hellerström, just like Musger and Marchionini previously, held his lecture in the Academy after being invited by Kogoj. Similar circumstances brought to Zagreb the British team of dermatovenereologists led by Geoffrey Barrow Dowling (1891-1976), whose undated photograph is also in the Kogoj's collection of photo portraits. Dowling was a skin diseases consultant for St Thomas' and St John's Hospital, where he encouraged histopathological research and pointed out benefits of applying high doses of calciferole in the treatment of lupus vulgaris. He also founded the famous Dowling Club, which enlisted Kogoj as one of its members in 1959. In that year, a group of British dermatologists headed by Dowling visited Zagreb's Department of Dermatovenereology, as well as the Academy, where "a public meeting" was held $^{59}$. Despite high workload, Kogoj continued to publish in the Academy's Rad. In 1963, he gave a lecture in the Academy about Mal de Meleda, and in the same year this lecture was published by the Academy.
Figure 10 Award by the Anti-Fascist Council for the National Liberation of Yugoslavia on the occasion of the 100th anniversary of YASA, Belgrade, 1966, HMMF-4507

In the sixties, Kogoj sped up his activities related to allergology. During 1961, he organized the First Congress of Yugoslav Allergologists, as well as symposia on allergology in 1964 and 1967. It was his initiative on April 16, 1965 that led to the founding of YASA's Allergology Center on Hvar, "as a scientific research institute within the Academy's Department of Medical Sciences"60. Members of the Expert Committee of the Center were, according to the decision by the Academy's Presidency on July 1, 1965, Branimir Gušić, Arpad Hahn, Zlatan Sremec and Milorad Mimica, while Franjo Kogoj was the head of the Expert Committee and the Center itself. The Director of the Allergollogy Center on Hvar was Želimir Dujmović, who trained in the Netherlands specifically for this role. During 1965, Kogoj participated at a meeting of the German Society for Allergology in Freiburg and Budapest, again with the Academy's support ${ }^{61}$.

On the occasion of the $100^{\text {th }}$ anniversary of the Yugoslav Academy of Sciences and Arts in 1966, Kogoj received an award by the Anti-Fascist Council for the National Liberation of Yugoslavia, which is also preserved in his collection (Figure 10).

On June 30, 1967 elections for the Academy's Presidency were being held. Grga Novak was again elected President, while Kogoj was again elected Vice-President with 72 votes out of $74^{62}$. Kogoj was the recipient of prestigious charters for his contributions, especially in German speaking regions. Of particular importance is his election to the membership of the German Leopoldina (1966), the Austrian Academy of Science (1971) and the Swiss Academy of Medical Sciences (1964).

In the seventies, Kogoj still focused on allergology. He organized the Dies italico-jugoslavici medicinae destinati in 1968, 1971, 1972 and $1974^{63}$. In the period between 1967 and 1974, he was the Director of the Institute for Clinical Medical Research of the School of Medicine and the University Hospital Center Zagreb. In 1970, the Academy published Kogoj's book Bolesti kože [Skin Diseases] $]^{64}$. The first number of Glasnik Alergološkog centra JAZU [Bulletin of the Allergology Center YASA], the first journal in Yugoslavia dedicated wholly to allergology, was published in 1972. This important undertaking, according to Vinko Bogdanić, would not be possible without Kogoj ${ }^{65}$ (Figure 11). Kogoj's involvement in the Allergology Center's council and the editorial board of the Bulletin lasted until September of 1973, when the Department of Medical Sciences accepted Kogoj's resignation ${ }^{66}$.

At the meeting of the Academy's Assembly on March 15, 1972, members of the Academy thanked Kogoj, whose mandate as Vice-President ended. On that occasion Fellow of the Academy Branimir Gušić stated that although he had participated only in the final three out of thirteen years of Kogoj's mandate in the Presidency, he knew that in the most difficult situations which required careful thinking, it was always Kogoj who knew how 


\title{
SAVIET CENTRA ZA ZAŠTITU KULTURNE BAŠTINE KOMUNE HVARSKE
}

\author{
O D A I E O V I M E
}

\section{PRIZNANJE}

\section{AKADEMIK PROFESOR DR. FRAN KOGOJ}

\author{
ZA RAD NA OČUVANIU KULTURNE BAŠTINE \\ OTOKA HVARA \\ Time štoje svojim blagorodnim čovjekoljubivim odnosom $i$ autoritetom učenjaka podstakao \\ mnoge humane manifestacije i ostvarenja Jugoslavenske akademije u Hvaru, čime je zadužio \\ narod Hvara, komunu iovaj Centar
}

HVAR, 1. rujna 1974

L

PREDSIEDNIK

Figure 11 Acknowledgment for the preservation of culture heritage of the island of Hvar, Hvar, 1974, HMMF-4461

to find the best solution. Among those who thanked Kogoj for his work in the Presidency was Grga Novak, who said: "During these thirteen years, which is not a short amount of time, he was always a best friend and a best adviser" ${ }^{\prime 67}$.

Kogoj had an interest in a variety of topics in dermatovenereology, trying to assess the specificities of local dermatopathology in their relation to global knowledge. His work in the Yugoslav Academy of Sciences and Arts underlines this aspect, especially concerning his attempts to accommodate dermatovenereology within a broader social and cultural context. In that respect, Kogoj's legacy outlines the establishment and the development of institutions, scientific publishing, networking, cooperation and knowledge exchange, research in dermatovenereology and allergology, while contributing to the Croatian medical history and attempting to collect medical and veterinary terminology. Apart from this lasting legacy, Kogoj left the Academy a segment of his material heritage: a bust by Vanja Radauš, which his daughter Breda Kogoj Kapetanić donated to Gliptotheque CASA in 2015, as well as the collection of photo portraits and charters which are now kept in the Croatian Museum of Medicine and Pharmacy CASA.

\section{LITERATURE:}

1. Franjo (Fran) Kogoj. In: Gušić B, ed. Ljetopis za godine 1946-1948. Zagreb: JAZU; 1949. p. 172-7.

2. Musger A. Franz Kogoj zum 70. Geburtstag. Hautarzt. 1964;15:5778.

3. Čajkovac Š. Akademik Franjo Kogoj - povodom 70. godišnjice života. Liječ Vjesn. 1965;85(1):6-10.

4. Schwarzwald M. Akademik Franjo Kogoj. Radovi Medicinskog fakulteta u Zagrebu. 1969;17(2):71-3.

5. Schwarzwald M. U povodu osamdesete obljetnice akademika prof. dr. Frana Kogoja. Acta dermatovenerol Iugoslav. 1974;1(4):191-4.

6. Stevanović DV. 80 Jahre am 13. Oktober 1974 (Porträit). Dermatologische Monatsschrift (Leipzig). 1974;160:886.

7. Zbornik liječnika Hrvatske 1874-1974. Zagreb: ZLH; 1974. p. 443-4.
8. Dugački V. Akademik Franjo Kogoj. Naše novine. 1983;6(54):4.

9. Brnobić A. Akademik prof. dr. Franjo Kogoj. Liječ Vjesn.

1984;106(1):44-5.

10. Živković D. Prva godišnjica smrti akademika Franje Kogoja. Psoriasis. 1984;9(18):4-5.

11. Holubar K. Franjo Kogoj and the Spongiform Pustule. Am J Dermatopath. 1985;7(2):191-5.

12. Holubar K. Franjo Kogoj i spongiformna pustula. Psoriasis. 1988;13(25):25-7.

13. Dobrić I. Psoriasis pustulosa: klasifikacija i svjetlosna mikroskopija: (Prigodom 70-te obljetnice Kogojeve spongiformne pustule 1927-

1997). Psoriasis. 1997;22(39):6-9.

14. Živković D. Franjo Kogoj i spongiformna pustula. Psoriasis. 1997;22(39):10-2. 
15. Fatović-Ferenčić $S$. The Chair of Dermatovenereology at Zagreb School of Medicine. Acta dermatovenerol Croat. 2001;9(4):267-73. 16. Franjo Kogoj and the Spongiform Pustule. In: Crissey HT, Parish LC, Holubar K, eds. Historical Atlas of Dermatology and Dermatologists. London: The Partenon Publishing Group; 2002. p. 123.

17. Muzur A. O spolnim bolestima Kogoju u čast: Prikaz skupa "Venereal Diseases: Realites \& Taboos” održanog u HAZU 28. svibnja 2003. AMHA 2003;1(2):227-8.

18. Fatović-Ferenčić S. Kogoj, Franjo (Fran). In: Macan T, ed. Hrvatski biografski leksikon: Knj. 7: Kam-Ko. Zagreb: Hrvatski leksikografski zavod Miroslav Krleža; 2009. p. 469.

19. Fatović-Ferenčić S. Croatian dermato-venereology. In: Scholz A, Holubar K, Burg W, eds. History of German Language Dermatology. Darmstadt: Wiley-Blackwell; 2009. p. 609-15.

20. Loser C, Plewig G, Burgdorf W. Pantheon of Dermatology: Outstanding Historical Figures. Berlin: Springer; 2013. p. 607-9.

21. Midžić S. Komemoracija Franji Kogoju. In: Ikić D, ed. Spomenica preminulim akademicima. Zagreb: JAZU; 1985. p. 28.

22. Midžić S, Belicza B. Život i djelo akademika Franje Kogoja. In: Dekaris D, Buneta D, eds. Rad HAZU. 1994;466(27):11-8.

23. Brnobić A, Lipozenčić J. Uloga Franje Kogoja u razvoju alergologije i kliničke imunologije u dermatovenerologiji u Hrvatskoj. In: Dekaris D, Buneta D, eds. Rad HAZU. 1994;466(27):19-28.

24. Fatović-Ferenčić S. Beginnings and development of allergology in Croatia from 1870-1970. In: Pećina M, ed. Rad HAZU. 2008;499(32):35-52.

25. Lipozenčić J, Brnobić A. Academician Franjo Kogoj and allergology in Croatia. In: Pećina M, ed. Rad HAZU. 2008;499(32):53-66.

26. Pećina M, Fatović-Ferenčić S. Uglednici u medicini: Poveznica Medicinskog fakulteta Sveučilišta u Zagrebu i Hrvatske akademije znanosti i umjetnosti. In: Pećina M, Klarica M, eds. Monografija Medicinskog fakulteta u povodu stote obljetnice. Zagreb: Medicinski fakultet Sveučilišta u Zagrebu; 2017. p. 201-4.

27. Kogoj F. Genitale und extragenitale Primäraffekte. In: Jadassohn J, ed. Handbuch der Haut- und Geschlechtskrankheiten. Berlin: Springer; 1930. p. 1-146.

28. Kogoj F. Terapija sifilisa: "kritični momenat" kao bitna točka u antiluetičnom liječenju: sa 13 diagrama. Zagreb: Nakladna knjižara "Juraj Križanić"; 1946.

29. Kogoj F. Dermatovenerološka propedeutika: opća dermatologija i terapija za medicinare i liječnike. Zagreb: Nakladni zavod Hrvatske; 1947.

30. Kogoj F. Problematika ekzema. Zagreb: JAZU; 1947.

31. Biografije novih članova: Franjo Kogoj. In: Gušić B, ed. Ljetopis za godine 1946-1948. Zagreb: JAZU; 1949. p. 172-7.

32. Kogoj F. Problematika ekzema. Rad JAZU. 1948;273(1):27-116.

33. Kogoj F. O alergiji. In: Kostrenčić M, ed. Ljetopis za godine 19491950. Zagreb: JAZU; 1952. p. 139.

34. Kogoj F. Terapija sifilisa. Zagreb: JAZU; 1949.

35. Kogoj F. The critical moment in syphilis treatment and times of examination of the spinal fluid. Acta Dermatol Venereol. 1952;32:86. 36. Dugac Ž, Fatović-Ferenčić S, Kovačić L, Kovačević T. The care for health cannot be limited to one country or one town only, it must extend to the entire world: The role of Andrija Štampar in the building of the World Health Organization. Croat Med J. 2008;49:697-708. 37. Kogoj F. Dermatoses professionelles allergiques et non allergiques. Symposium sur les dermatoses professionalles. Bil Soc Fr Dermat et Syph. 1955;2:210-5.

38. Kogoj F. Naš endemski sifilis i njegovo liječenje. Liječ Vjesn. 1932;54:1-3.

39. I. redovno zasjedanje skupštine JAZU 30. ožujka 1950. In: Kostrenčić M, ed. Ljetopis za godine 1949-1950. Zagreb: JAZU; 1952. p. 116.

40. Moguš M, ed. 140 godina Hrvatske akademije znanosti i umjetnosti 1861. - 2001. Zagreb: HAZU; 2001. p. 111-3.

41. Kogoj F, ed. Simposion o alergiji. Zagreb: JAZU; 1952.

42. Mimica M. Alergološka sekcija. In: Keros P, ed. Zbornik liječnika Hrvatske. Zagreb: ZLH; 1974. p. 203-4.

43. Marchionini A. Novi pogledi na etiologiju kožnih bolesti. In: Kostrenčić M, ed. Ljetopis za godine 1951-1952. Zagreb: JAZU; 1954. p. $148-9$.

44. Kogoj F, ed. Izvješća dermatovenerološke klinike u Zagrebu. Knjiga 1-2. Zagreb: JAZU; 1952.

45. Kogoj F. Kritički moment kao opća koncepcija antiluetičnoga liječenja. In: Kogoj F, ed. Izvješća dermatovenerološke klinike u Zagrebu. Knjiga 1-2. Zagreb: JAZU; 1952. p. 203-8.

46. Kostrenčić M, ed. Ljetopis za godinu 1954. Zagreb: JAZU; 1956. p. 26.

47. Kogoj F. Generalizirana kandidijaza nalik na vegetirajući herpetiformni dermatitis. Rad JAZU. 1955;307(5):5-24.

48. I. redovno godišnje te izvanredno zasjedanje Skupštine 16. III. 1954. In: Kostrenčić M, ed. Ljetopis za godinu 1954. Zagreb: JAZU; 1956. p. 84.

49. Marchionini A. Fr. Kogoj zum 60. Geburtstag. Hautarzt 1955;6(10):479.

50. Grmek MD. Hrvatska medicinska bibliografija 1470. - 1875. Zagreb: JAZU; 1955.

51. Grmek MD. Hrvati i Sveučilište u Padovi. In: Kostrenčić M, ed. Ljetopis za godinu 1955. Zagreb: JAZU; 1957. p. 334-74.

52. Izvješće Odjela za medicinske nauke. In: Novak G, Kostrenčić M, eds. Ljetopis za godinu 1956. Zagreb: JAZU; 1959. p. 69-72. 53. Izvješće Odjela za medicinske nauke. In: Novak G, ed. Ljetopis za godinu 1958. Zagreb: JAZU; 1961. p. 86.

54. Redovno godišnje i izvanredno zasjedanje Skupštine JAZU održano 12. ožujka 1958. In: Novak G, ed. Ljetopis za godinu 1958. Zagreb: JAZU; 1961. p. 40.

55. Izvješće Grge Novaka za 1959. godinu. In: Mirković M, ed. Ljetopis za godinu 1959. Zagreb: JAZU; 1962. p. 41.

56. Proslava 50-godišnjice Medicinskog fakulteta u Zagrebu. Liječ Vjesn. 1968;90:1141. 
57. Kesić B. Anton Musger (1898.-1983.). In: Požar H, ed. Ljetopis za godinu 1983. Zagreb: JAZU; 1984. p. 551-2.

58. Prvo redovno godišnje zasjedanje skupštine JAZU održano 29. ožujka 1960. In: Mirković M, ed. Ljetopis za godinu 1960. Zagreb: JAZU; 1963. p. 44.

59. Izvještaj Odjela za medicinske nauke. In: Mirković M, ed. Ljetopis za godinu 1960. Zagreb: JAZU; 1963. p. 94.

60. Izvještaj Odjela za medicinske nauke. In: Karšulin M, ed. Ljetopis za godinu 1966. Zagreb: JAZU; 1969. p. 106.

61. Alergološki centar u Hvaru. In: Karšulin M, ed. Ljetopis JAZU za godinu 1966. Zagreb: JAZU; 1969. p. 108.

62. Izvanredno zasjedanje Skupštine JAZU. In: Karšulin M, ed. Ljetopis za godinu 1967. i 1968. Zagreb: JAZU; 1970. p. 160.

63. Brnobić A, Lipozenčić J. Uloga Franje Kogoja u razvoju alergologije i kliničke imunologije u dermatovenerologiji u Hrvatskoj. Rad HAZU. 1994;466(27):23.

64. Kogoj F. Bolesti kože 1-2. Zagreb: JAZU; 1971-1972.

65. Bogdanić V. Smisao Alergološkog centra Dr. O. Žunković JAZU u Hvaru. In: Miličić D, ed. Hvar u prirodnim znanostima: zbornik radova. Zagreb: JAZU; 1977. p. 69-70.

66. Division for the History of Medical Sciences, CASA. File Franjo Kogoj. Letter from Sead Midžić to Vinko Bogdanić, October 4, 1973. 67. Izvanredno zasjedanje Skupštine Jugoslavenske akademije znanosti i umjetnosti održano 15. ožujka 1972. In: Škreb N, ed. Ljetopis za godinu 1972. Zagreb: JAZU; 1973. p. 220. 